University of Nebraska - Lincoln

DigitalCommons@University of Nebraska - Lincoln

\title{
Effects of crustal stresses on fluid transport in fractured rock: case studies from northeastern and southwestern USA
}

Roger H. Morin

Denver Federal Center, roger.morin49@gmail.com

William Z. Savage

US Geological Survey, Denver

Follow this and additional works at: https://digitalcommons.unl.edu/usgsstaffpub

Part of the Earth Sciences Commons

Morin, Roger H. and Savage, William Z., "Effects of crustal stresses on fluid transport in fractured rock: case studies from northeastern and southwestern USA" (2003). USGS Staff -- Published Research. 353. https://digitalcommons.unl.edu/usgsstaffpub/353

This Article is brought to you for free and open access by the US Geological Survey at DigitalCommons@University of Nebraska - Lincoln. It has been accepted for inclusion in USGS Staff -- Published Research by an authorized administrator of DigitalCommons@University of Nebraska - Lincoln. 


\title{
Effects of crustal stresses on fluid transport in fractured rock: case studies from northeastern and southwestern USA
}

\author{
Roger H. Morin · William Z. Savage
}

\begin{abstract}
The link between stress and hydrologic properties was examined at two sites that are distinguished by different rock types and different stress states. This investigation is based upon the analysis and interpretation of geophysical logs obtained in water wells at the two locations. At the northeast site (Newark Basin), the hydrologic characteristics of sedimentary rocks are dependent upon the relationship to the current regional stress field of two primary types of orthogonal features that serve as preferential pathways for fluid flow. Subhorizontal bedding-plane partings are highly transmissive near the surface and delineate transversely isotropic fluid flow at shallow depths. With increasing depth, the subhorizontal planes become less dominant and steeply dipping fractures become more influential hydrologically. These high-angle features define anisotropic flow pathways that are preferentially oriented along strike. At the southwest site (west Texas), extrusive rocks are subjected to topographically modified tectonic and gravitational stresses that vary spatially within a valley setting. The attendant changes in stress invariants cause fracture connectivity within the rock mass to systematically increase with depth along the valley flanks, but to remain relatively low in the central valley. The degree of fracture connectivity predicted within this valley configuration is consistent with variations in transmissivity determined at several well locations. In each of these cases, the idealized understanding of the hydrologic system is enhanced by considering the effects of regional and local stresses that act upon the fractured-rock aquifer.
\end{abstract}

Résumé La relation entre les propriétés hydrologiques et la contrainte est étudiée sur deux sites distincts par les types de roches et leurs états de contraintes différents. Cette étude est basée sur l'analyse et l'interprétation de logs géophysiques obtenus dans des puits en deux en-

Received: 23 August 2001 / Accepted: 28 October 2002

Published online: 15 January 2003

(C) Springer-Verlag 2003

R. H. Morin · W. Z. Savage (

US Geological Survey, Denver, Colorado 80225, USA

e-mail: savage@usgs.gov droits. Sur le site nord-est (le bassin de Newark), les caractéristiques hydrologiques des roches sédimentaires dépendent de la relation entre le champ actuel de contraintes régionales et les deux types primaires de plans orthogonaux conduisant préférentiellement les écoulements souterrains. Les plans de stratification subhorizontaux sont très transmissifs près de la surface et déterminent transversalement un écoulement isotrope aux faibles profondeurs. Avec l'accroissement de la profondeur, les plans subhorizontaux deviennent moins importants et les fractures à fort pendage jouent un rôle hydrologique plus déterminant. Ces plans sécants à grands angles définissent des écoulements anisotropes préférentiels selon leur orientation. Sur le site sud-ouest (Texas occidental), des roches effusives ont contribué à modifier topographiquement les contraintes tectoniques et gravitationnelles qui varient spatialement selon la disposition de la vallée. Les changements associés aux invariants de la contrainte sont la cause d'un accroissement systématique de la connectivité de fractures de la masse rocheuse en profondeur sur les flancs de la vallée; la connectivité reste cependant relativement faible au centre. Le degré de connectivité de fracture prédit dans cette configuration de la vallée est compatible avec les variations de transmissivité déterminées dans des puits en plusieurs endroits. Dans chacun de ces cas, notre compréhension théorique du système hydrologique est améliorée par la prise en compte des effets des contraintes régionales et locales qui agissent sur l'aquifère fracturé.

Resumen Se examina el nexo entre los esfuerzos y las propiedades hidrológicas en dos emplazamientos que se distinguen por tener diferentes litologías y estados tensionales. La investigación está basada en el análisis e interpretación de registros geofísicos obtenidos en pozos de ambos lugares. En el emplazamiento situado al Nordeste (cuenca Newark), las características hidrológicas de las rocas sedimentarias dependen de la relación con el campo regional de esfuerzos actual de dos tipos primarios de características ortogonales que actúan como caminos preferentes de flujo. Las separaciones subhorizontales del plano de estratificación son muy transmisivas cerca de la superficie y delinean un flujo transversal isótropo a profundidades someras. A mayor profundidad, los planos subhorizontales son menos dominantes, mientras que las fracturas con buzamientos acusados se con- 
vierten en hidráulicamente más influyentes. Estas fracturas de alto ángulo definen esquemas anisótropos de flujo que se orientan preferentemente a lo largo de su dirección. En el emplazamiento del Sudoeste (oeste de Texas), las rocas extrusivas están sometidas a tensiones tectónicas modificadas por la topografía y a tensiones gravitacionales que varían espacialmente dentro del valle. Los cambios consiguientes en invariantes de los esfuerzos crean conectividades entre fracturas del macizo rocoso, que aumentan sistemáticamente con la profundidad a la largo de los flancos del valle, pero son relativamente bajas en la zona central. El grado de conectividad de las fracturas predicho con esta configuración del valle es coherente con las variaciones de transmisividad determinadas en diferentes pozos. En cada caso, nuestro conocimiento idealizado del sistema hidrológico mejora si consideramos los efectos de los esfuerzos regionales y locales que actúan en el acuífero formado por rocas fracturadas.

Keywords Crustal stresses $\cdot$ Fluid transport $\cdot$ Fractured rock $\cdot$ USA

\section{Introduction}

In numerous hydrogeologic investigations of fracturedbedrock aquifers, groundwater flow has been shown to be primarily controlled by a network of interspersed discontinuities rather than by a primary matrix porosity. A variety of fractures, joints, and bedding planes particular to certain lithologic units, along with their orientations, spatial distributions, and transmissivities, combine to establish a hierarchical system of pathways for fluid transport (e.g., Moreno and Neretnieks 1993; Ouillon et al. 1996; Clemo and Smith 1997).

It is generally recognized that the mechanical response of a rock mass to physical loading produces deformation and possibly failure that can be predicted from rock-mechanics principles; Pollard and Aydin (1988), for example, cite numerous studies that relate joint orientation to current and past tectonic stress fields. Clusters of planar features often appear as subsets of a general fracture population and their occurrence may be a direct result of local and far-field stresses imposed upon the rock (e.g., Einstein and Dershowitz 1990).

Imposed stresses may cause the hydraulic characteristics of a rock mass to be significantly affected (Simpson et al. 2001). Laboratory studies (Bruno et al. 1991; Gentier et al. 2000) and complementary network models (Sayers 1990; Renshaw 2000) demonstrate that transmissivity anisotropy develops in a fractured medium in response to applied stresses as some planes are systematically closed whereas others are preferentially propped open. Barton et al. (1995) present geophysical logs obtained from several sites that indicate an enhanced hydraulic conductivity associated with faults that are optimally oriented for failure in the contemporary stress field. Ferrill et al. (1999) similarly identify anisotropic transmissivity conditions at Yucca Mountain, Nevada, presumably controlled selectively by faults and fractures that are active under present-day in situ stresses. In petroleum-recovery operations, Bell and Babcock (1986) and Heffer et al. (1995) report a strong correlation between the directionality of reservoir flow during water flooding and the local orientation of horizontal stresses in the shallow crust.

In this paper, the link between stress and groundwater transport was examined based upon the analysis and interpretation of geophysical logs obtained in water wells at two sites that are distinguished by different rock types and different states of stress. In each case, our conceptual understanding of the groundwater system is enhanced by considering the regional and local stresses that act upon the fractured-rock aquifer.

\section{Newark Basin Case Study Northeast}

\section{Hydrogeologic Setting}

The Newark Basin (Fig. 1) is an elongated $(210 \times 55 \mathrm{~km})$, northeast-southwest trending rift basin filled with late Triassic and early Jurassic fluvial and lacustrine sediments (Olsen 1980; Parker et al. 1988). These deposits consist of gradational sequences of mudstone, siltstone, and sandstone, and encompass important regional aquifers such as the Brunswick Group and the Passaic Formation (Froelich and Robinson 1988). Primary porosity is typically low (3-5\%) in these lithified rocks and fractures form the dominant pathways for groundwater flow (Michalski and Britton 1997).

Field studies designed to investigate the hydrology of the Newark Basin through the analysis of geophysical logs have been undertaken at sites in New Jersey (Morin et al. 1997) and in Pennsylvania (Morin et al. 2000; Fig. 1). The understanding of the hydrogeology is formulated by integrating a variety of complementary field approaches such as surface and borehole geophysics, aquifer tests, and packer experiments. Field results were similar for both locations, indicating a certain spatial consistency in general hydrologic properties across this Basin. The Newark Basin resembles stratigraphically about 25 other inland rift basins along the east coast of North America from South Carolina to Nova Scotia, and groundwater studies at other sites (e.g., Stone et al. 1996) also reveal common, reoccurring characteristics. Thus, the fractured-rock aquifers underlying the sites in New Jersey and Pennsylvania display similarities from both an interbasin and an intrabasin perspective.

\section{Geophysical Log Analysis and Results}

Geophysical logs were recorded in Hopewell Township, New Jersey (ten wells with average depth of $\sim 46 \mathrm{~m}$ ) and in Lansdale, Pennsylvania (seven wells with average depth of $\sim 120 \mathrm{~m}$ ). These logs consisted of caliper, temperature, fluid conductivity, formation resistivity, natural gamma activity, acoustic borehole televiewer, and heat- 


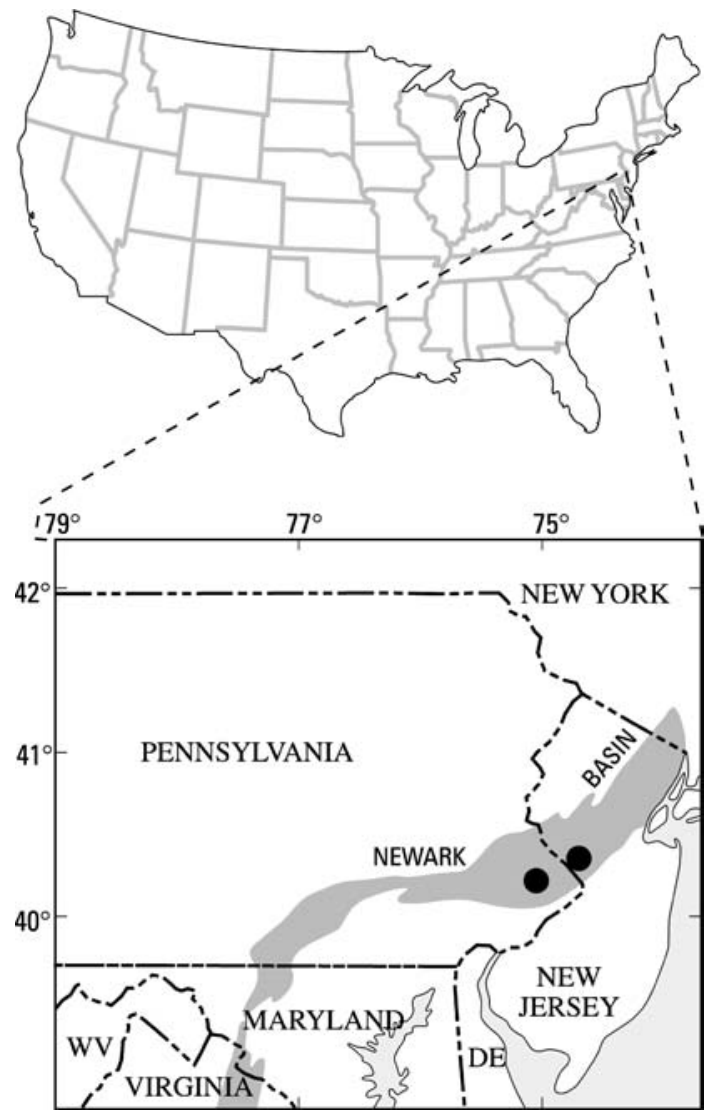

Fig. 1 Location of Newark Basin and study sites (black dots) in New Jersey and Pennsylvania

pulse flow meter under ambient and disturbed conditions (pumping or injection). Additional information regarding these tools and their principles of operation may be found in Hearst et al. (2000). The logs were analyzed to delineate lithologic units, to identify individual fracture planes and determine their spatial distribution, to recognize fracture types associated with particular units, and to distinguish permeable fractures from the general fracture population and quantify their transmissivities (Morin et al. 1997, 2000).

A rosette and a lower-hemisphere stereographic plot of fracture orientations from the New Jersey site depict a predominant east-west direction (Fig. 2). These diagrams, constructed from inspection of the acoustic televiewer logs, reveal two conspicuous subsets of planes that share a common strike and are orthogonal to each other. A similar fracture distribution, with a more $\mathrm{NE}-\mathrm{SW}$ orientation $\left(\mathrm{N} 45^{\circ} \mathrm{E}\right)$ was found at the Pennsylvania site. Complementary gamma and resistivity logs provide information on lithology from which it is determined that the shallow dipping features represent bedding-plane partings associated with mudstones and siltstones, whereas the high-angle features represent brittle fractures in dense sandstones.

Additional fluid-property logs and flow meter measurements indicate that the bedding planes are highly transmissive near the surface and that these partings reg-
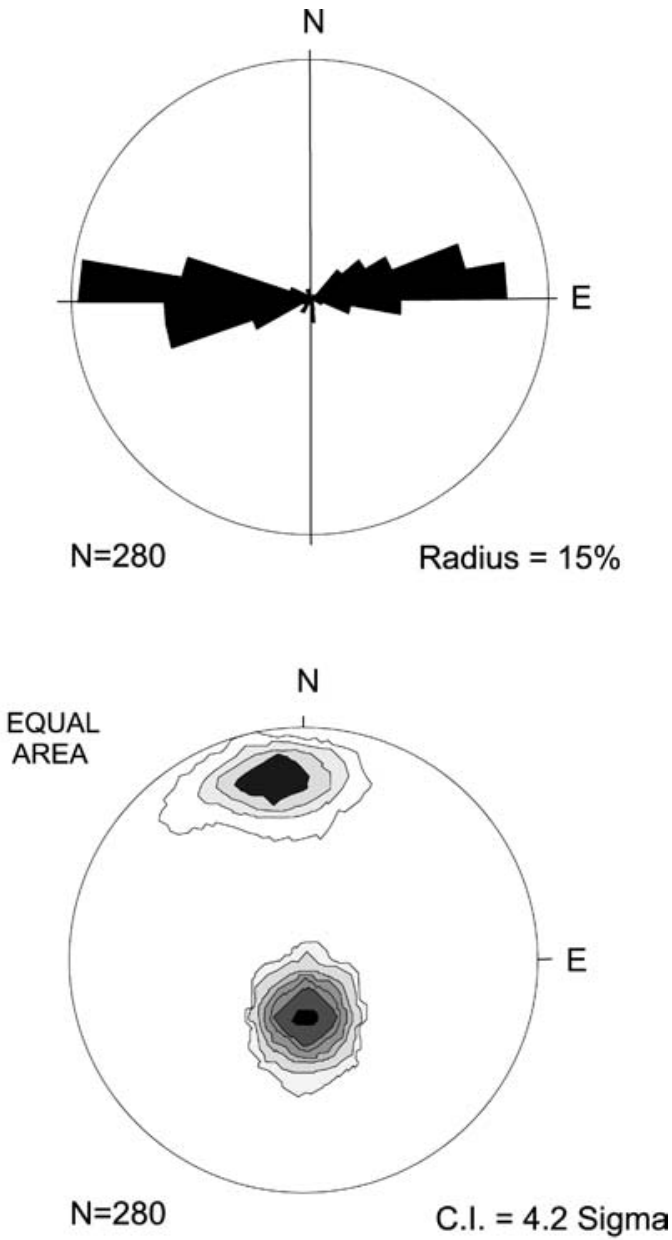

Fig. 2 Rosette and lower hemisphere stereographic diagrams of fracture orientations identified from televiewer logs in New Jersey (modified from Morin et al. 1997). N Number of planes; C.I. statistical contour interval

ulate shallow groundwater movement. With increasing depth, these planes become less dominant and the steeply dipping but less transmissive fractures begin to be more influential in controlling fluid transport. The observed high-angle fractures span a narrower depth-independent range of transmissivities than do the subhorizontal partings and intersections of the two types of features have a very narrow transmissivity range (Fig. 3).

Subhorizontal bedding-plane partings promote transversely isotropic fluid flow, whereas subvertical fractures delineate flow pathways that are preferentially oriented along strike and that are highly anisotropic (Vecchioli et al. 1969). Thus, the general hydrologic response of the aquifer is closely related to fracture type and fracture type is related to lithology.

\section{Tectonic Setting}

The Newark Basin, formed by crustal extension, is filled with sedimentary rocks that generally strike eastnortheast/west-southwest and dip slightly to the northnorthwest. This homoclinal structure is observed in 


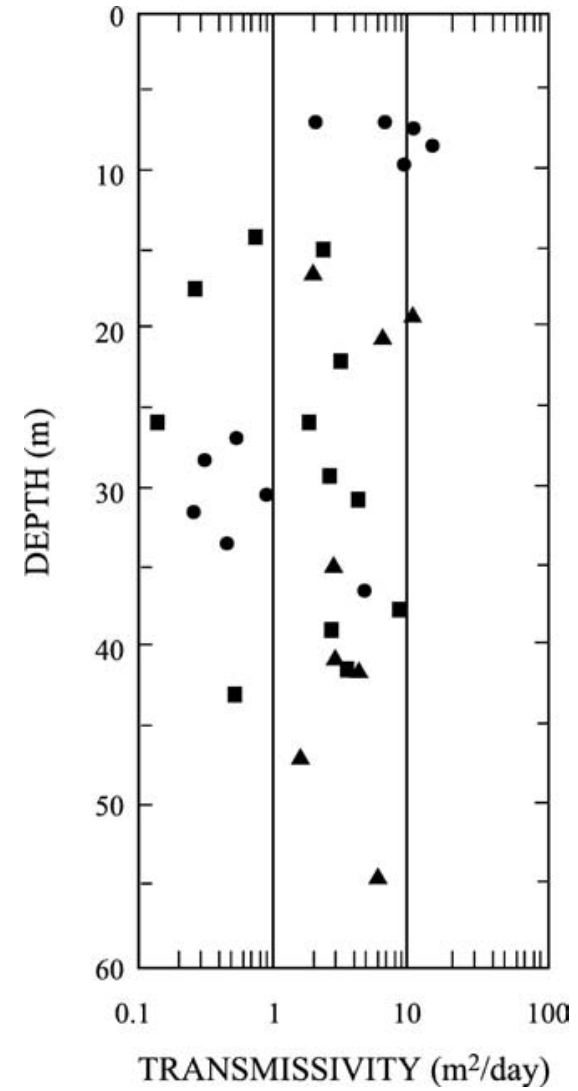

Fig. 3 Transmissivities of the two fracture types and of their intersections as a function of depth at the New Jersey site. Beddingplane partings (circles), high-angle fractures (squares), and intersections of both (triangles) are identified (from Morin et al. 1997)

much of the Basin, although it is occasionally interrupted by intrabasin faults and distorted by transverse folds (Schlische 1992). Approximately $8 \mathrm{~km}$ north of the Pennsylvania site is the Chalfont Fault, a left-lateral, intrabasinal fault that strikes northwest-southeast. The Hopewell Fault, a major regional tectonic feature, is only $2 \mathrm{~km}$ northwest of the New Jersey study site. Other nearby regional structures include broad, low amplitude folds (Lyttle and Epstein 1987) with mostly gentle topographic relief.

Zoback and Zoback (1989) summarize contemporary principal stress orientations for the eastern United States, including the Newark Basin, and present the orientation of the greatest horizontal principal stress, $S_{H}$, as NE-SW to E-W. Seeber et al. (1998) argue that the least horizontal principal stress, $S_{h}$, and the vertical principal stress, $S_{v}$, have similar magnitudes in the Newark Basin and would be expected to change relative positions, thereby resulting in both thrust $\left(S_{H}>S_{h}>S_{v}\right)$ and strike-slip $\left(S_{H}\right.$ $>S_{v}>S_{h}$ ) faulting. These investigators also apply source data from a number of recent earthquakes in the Newark Basin to a fault kinematic model proposed by Michael (1984) to establish the direction of $S_{H}$ and the principal stress ratios for the region. Their results estimate the direction of $S_{H}$ to be $\mathrm{N} 68^{\circ} \mathrm{E}$, with stress ratios $S_{H} / S_{h}=2.25$ and $S_{v} / S_{h}=1.15$. This $S_{H}$ direction bisects the average

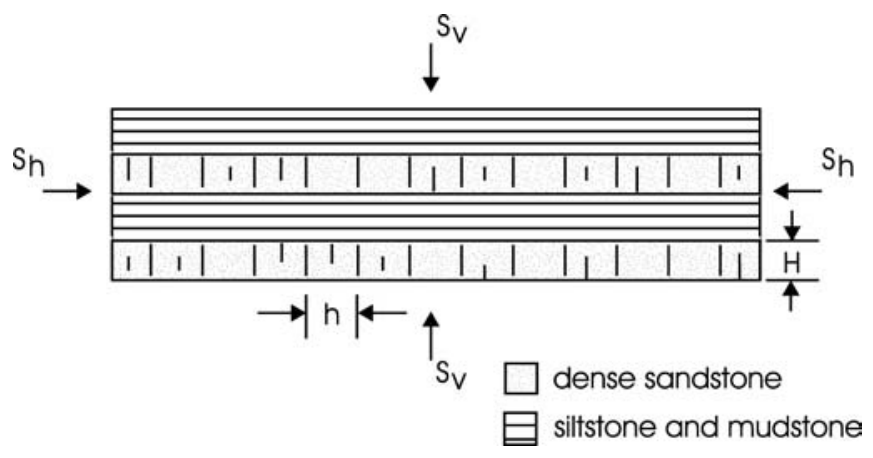

Fig. 4 Diagram of typical basin stratigraphy, with $h$ being the spaced cleavage dimension and $H$ the unit thickness. Here $S_{H}$, the maximum horizontal principal stress, acts normal to the plane of the figure, $S_{h}$ is the minimum horizontal principal stress, and $\mathrm{S}_{v}$ is the vertical principal stress

fracture orientations determined at the two study sites, which are E-W in New Jersey and $\mathrm{N}^{\circ} 5^{\circ} \mathrm{E}$ in Pennsylvania.

Sedimentary rocks in the Newark Basin have undergone two general types of deformation in response to past tectonic stresses: (1) ductile deformation within softer, weaker siltstones and mudstones, and (2) brittle deformation with mechanical failure in stiffer, denser sandstones (Fig. 4). The features resulting from the former process include subhorizontal bedding plane partings and foliations in the mudstones and siltstones. Some of these have undergone opening at shallow depths with exhumation and the corresponding release of overburden stress. The features resulting from the latter tectonic process are high-angle extensional fractures that have a spaced cleavage in the relatively dense sandstones. These steeply dipping, subparallel fractures generally strike perpendicular to the current regional least principal stress, and the spatial frequency of their cleavage, $h$, is proportional to the thickness of the lithologic unit, $H$ (Fig. 4; Priest and Hudson 1976; Bai and Pollard 2000). Transmissivities associated with these fractures are not particularly sensitive to changes in vertical loading over the relatively shallow depths observed in well logging (Morin et al. 1997).

\section{Stress model}

To explain the influence of current crustal stresses on fluid flow in the Newark Basin, a model is presented for closure of rock fractures in response to a three-dimensional stress field and the effects of this closure on the hydraulic properties of the rock mass. Hillis (1998) presents a two-dimensional model for closure of fractures with varying alignment under the influence of the maximum and minimum horizontal principal stresses, $S_{H}$ and $S_{h}$. In Hillis' (1998) study, a semi-log relation was used (Bandis et al. 1983; Brown and Scholz 1986; Beeler and Hickman 2001) to represent closure of unmated fractures under normal stress. Unmated refers to a test in which the two halves of the rock sample on either side of a fracture have been displaced from their original posi- 
tions before applying compression normal to the joint. The model presented here considers the closure of mated fractures; mated fractures are those in which the two halves of the rock sample on either side of the fracture are left in the original relative positions before applying compression normal to the joint.

The relation for mated joint closure, $d$, as a function of normal stress, $\sigma_{n}$, is (Hudson and Harrison 1997),

$$
d=\frac{d_{m} \sigma_{n}}{\sigma_{n}+K_{i} d_{m}}
$$

where $d_{m}$ is the maximum joint closure and $K_{i}$ is defined as the initial joint stiffness. Joint stiffness has dimensions of stress per unit length. This expression is hyperbolic and joint closure asymptotically approaches a maximum value with increasing normal stress. Attendant joint aperture is given by $\varsigma \varsigma_{0}-d$, where $\varsigma_{0}$ is the initial joint aperture. Substituting this relation into Eq (1) yields,

$\varsigma=\varsigma_{0}-\frac{d_{m} \sigma_{n}}{\sigma_{n}+K_{i} d_{m}}$

The ratio $\varsigma / \varsigma_{0}$ equals 1 in the absence of a normal load and joint aperture, $\varsigma$, asymptotically approaches $\left(\varsigma_{0}-d_{m}\right)$ for large normal stress.

The normal stress, $\sigma_{n}$, acting on an arbitrarily oriented plane may be expressed in terms of the three principal stresses through Cauchy's formula (Jaeger and Cook 1977). Cauchy's formula may then be combined with Eq. (2) to predict the closure of particular planes under effective crustal stresses specified by $S_{H}{ }^{\prime}, S_{h}{ }^{\prime}$, and $S_{v}{ }^{\prime}$. These equations were incorporated in a computer program developed by Savage and Swolfs (1987) to provide the results depicted as stereographic projections in Fig. 5. Contours of dimensionless joint aperture, $\varsigma / \varsigma_{0}$, for dimensionless crustal stresses $S_{H}{ }^{\prime} / \mathrm{K}_{\mathrm{i}} \mathrm{d}_{\mathrm{m}}=2.25$, $S_{h}{ }^{\prime} / \mathrm{K}_{\mathrm{i}} \mathrm{d}_{\mathrm{m}}=1.00$, and $S_{v}{ }^{\prime} / \mathrm{K}_{\mathrm{i}} \mathrm{d}_{\mathrm{m}}=1.15$ are illustrated in Fig. 5a. For convenience and ease of referencing, the maximum horizontal stress, $S_{H}{ }^{\prime} / \mathrm{K}_{\mathrm{i}} \mathrm{d}_{\mathrm{m}}$, and the minimum horizontal stress, $S_{h}{ }^{\prime} / \mathrm{K}_{\mathrm{i}} \mathrm{d}_{\mathrm{m}}$, are oriented $\mathrm{E}-\mathrm{W}$ and $\mathrm{N}-\mathrm{S}$, respectively. These stress orientations differ somewhat from those determined by Seeber et al. (1998), but are generally consistent with principal stress directions for the northeastern United States (Zoback and Zoback 1989). The values of $2.25,1.00$, and 1.15 are the stress ratios determined by Seeber et al. (1998) from shallow $(<5 \mathrm{~km})$ earthquake focal mechanisms. It is apparent from Fig. 5a that the least closure occurs in near vertical joints oriented $\mathrm{E}-\mathrm{W}$, normal to the $\mathrm{N}-\mathrm{S}$ minimum horizontal stress, and that joints normal to the E-W maximum horizontal stress exhibit the greatest closure.

Contours of dimensionless joint aperture, $\varsigma / \varsigma_{0}$, for dimensionless crustal stresses $S_{H}{ }^{\prime} / \mathrm{K}_{\mathrm{i}} \mathrm{d}_{\mathrm{m}}=2.25, S_{h}{ }^{\prime} / \mathrm{K}_{\mathrm{i}} \mathrm{d}_{\mathrm{m}}=$ 1.00 , and $S_{v}{ }^{\prime} / \mathrm{K}_{\mathrm{i}} \mathrm{d}_{\mathrm{m}}=0.1$ are presented in Fig. 5b. As with the case described above, the maximum horizontal stress, $S_{H}{ }^{\prime} / \mathrm{K}_{\mathrm{i}} \mathrm{d}_{\mathrm{m}}$, is again assumed to be oriented $\mathrm{E}-\mathrm{W}$. However, the assumed vertical principal stress, $S_{v}{ }^{\prime} / \mathrm{K}_{\mathrm{i}} \mathrm{d}_{\mathrm{m}}$, is reduced to a magnitude of 0.1 to represent joint clo-

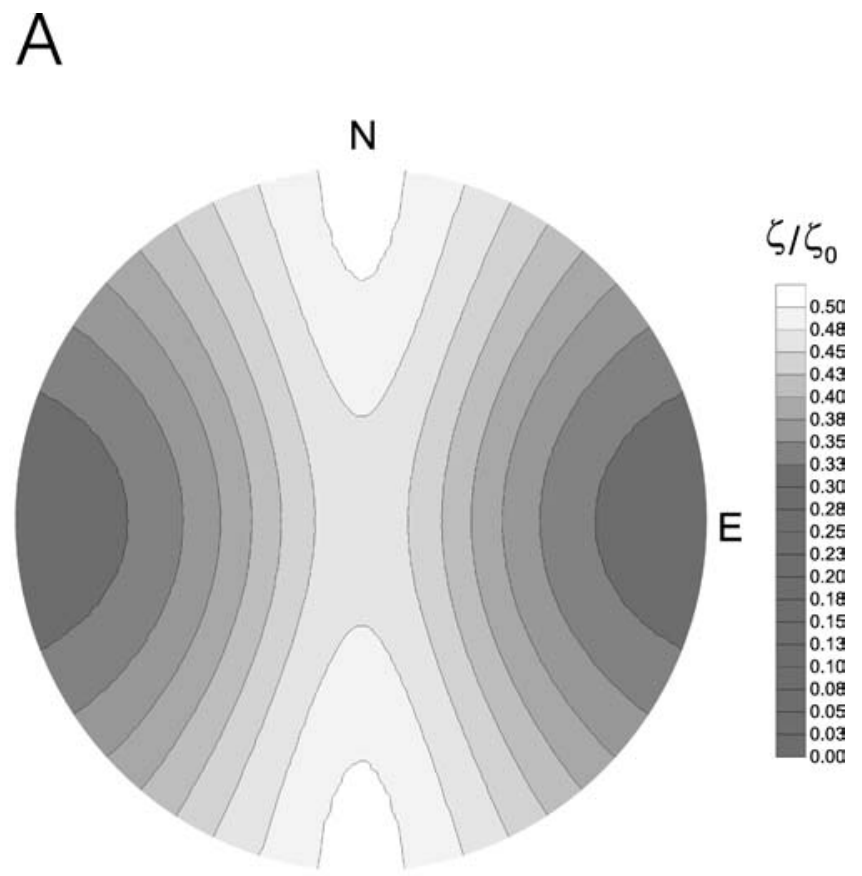

B

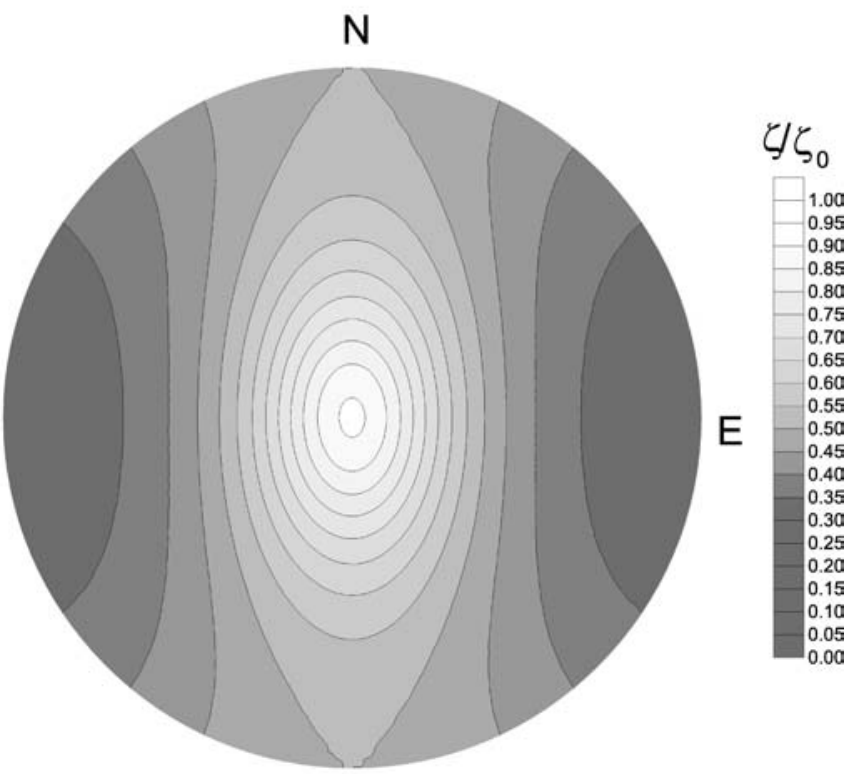

Fig. 5 Stereographic contour plots of dimensionless joint aperture, $\zeta / \varsigma_{0}$. A Dimensionless effective crustal stresses are $S_{H}{ }^{\prime} / \mathrm{K}_{\mathrm{i}} \mathrm{d}_{\mathrm{m}}=2.25, S_{h}{ }^{\prime} / \mathrm{K}_{\mathrm{i}} \mathrm{d}_{\mathrm{m}}=1.00$, and $S_{v}{ }^{\prime} / \mathrm{K}_{\mathrm{i}} \mathrm{d}_{\mathrm{m}}=1.15$. The maximum horizontal stress $S_{H}{ }^{\prime} / \mathrm{K}_{\mathrm{i}} \mathrm{d}_{\mathrm{m}}$ is oriented $\mathrm{E}-\mathrm{W}$ and the minimum horizontal stress $S_{h}{ }^{\prime} / \mathrm{K}_{\mathrm{i}} \mathrm{d}_{\mathrm{m}}$ is oriented $\mathrm{N}-\mathrm{S}$. B Dimensionless effective crustal stresses are $S_{H}{ }^{\prime} / \mathrm{K}_{\mathrm{i}} \mathrm{d}_{\mathrm{m}}=2.25, S_{h}{ }^{\prime} / \mathrm{K}_{\mathrm{i}} \mathrm{d}_{\mathrm{m}}=1.00$, and $S_{v}{ }^{\prime} / \mathrm{K}_{\mathrm{i}} \mathrm{d}_{\mathrm{m}}=$ 0.1 . The maximum horizontal stress $S_{H}^{\prime} / \mathrm{K}_{\mathrm{i}} \mathrm{d}_{\mathrm{m}}$ is again oriented $\mathrm{E}-\mathrm{W}$ and the vertical principal stress is that for near-surface stress conditions

sure near the surface where vertical loading is much smaller. It is apparent from Fig. 5b that subhorizontal planes oriented normal to the relatively small vertical stress retain the largest aperture and that those normal to 
the maximum horizontal stress suffer the greatest closure. The two diagrams presented in Fig. 5 are intended to provide a qualitative comparison of joint-closure response to stress in the "shallow" and "deep" subsurface. Absolute stress measurements have not been done in this study area and, consequently, absolute stress magnitudes and corresponding depths are not considered in this nondimensional approach. Such measurements would enable a detailed examination of the gradual transition in stress regimes that occurs between these shallow and deep bounds.

The cubic law (Witherspoon et al. 1980) may be used to model the effects of joint aperture on horizontal fluid flow. This law is given by,

$Q=\frac{\varsigma^{3}}{12 v R} \frac{d p}{d x}$

where $Q$ is discharge, $v$ is fluid viscosity, $\varsigma$, again, is aperture, $R$ is a factor accounting for joint surface roughness, and $d p / d x$ is the pressure gradient in the flow direction. Equation (3) has been confirmed to apply for fluid flow in rock joints having relatively large apertures and under low normal stresses by numerous investigators (Witherspoon et al. 1980; Cook 1992); this relation is plotted in dimensionless form in Fig. 6.

From Fig. 5A we see that for greater depths, where all the tectonic stress ratios given by Seeber et al. (1998) might be expected to hold, E-W oriented subvertical fractures have the largest dimensionless apertures $\left(c / \varsigma_{0}\right.$ $\approx 0.49$ ), subhorizontal fractures (e.g., bedding-plane partings) have slightly reduced dimensionless apertures $\left(\varsigma / \varsigma_{0}\right.$ $\approx 0.46$ ), and $\mathrm{N}-\mathrm{S}$-oriented vertical fractures have the smallest dimensionless apertures $\left(\varsigma / \varsigma_{0} \approx 0.30\right)$. A different situation is depicted for shallow depths in Fig. 5B. Here, where only the horizontal tectonic stress ratios given by Seeber et al. (1998) might be expected to hold and where the vertical stress ratio would be reduced because of proximity to the ground surface, subhorizontal fractures (e.g., bedding-plane partings) have the largest dimensionless apertures $\left(\varsigma / \varsigma_{0} \approx 0.90\right)$, and $\mathrm{E}-\mathrm{W}$ - and $\mathrm{N}-\mathrm{S}$ oriented vertical fractures have basically unchanged dimensionless apertures $\left(\varsigma / \varsigma_{0} \approx 0.53\right.$ and $\left.\varsigma / \varsigma_{0} \approx 0.30\right)$.

Using the predicted dimensionless aperture of $\varsigma / \varsigma_{0}$ $\approx 0.49$ for $\mathrm{E}-\mathrm{W}$-oriented fractures and $\varsigma / \varsigma_{0} \approx 0.46$ for horizontal fractures given in Fig. 5A, we find the dimensionless horizontal discharge, $Q^{*}=Q(\varsigma) / Q\left(\varsigma_{0}\right)$, to be on the order of 0.10 (Fig. 6) for these two categories of fractures under the tectonic stress ratios assumed to hold at depth. The dimensionless discharge for $\mathrm{N}-\mathrm{S}$ fractures with dimensionless aperture of 0.30 is estimated from Fig. 6 to be less than 0.05 at depth.

Using the predicted dimensionless apertures of $\varsigma / \varsigma_{0}$ $\approx 0.53$ for $\mathrm{E}-\mathrm{W}$-oriented fractures and $\varsigma / \varsigma_{0} \approx 0.90$ for horizontal fractures given in Fig. 5B, we find the dimensionless E-W discharge to be roughly 0.15 and the horizontal dimensionless discharge to be on the order of 0.75 (Fig. 6) for fractures subjected to the horizontal tectonic stress ratios and the smaller vertical stresses assumed to

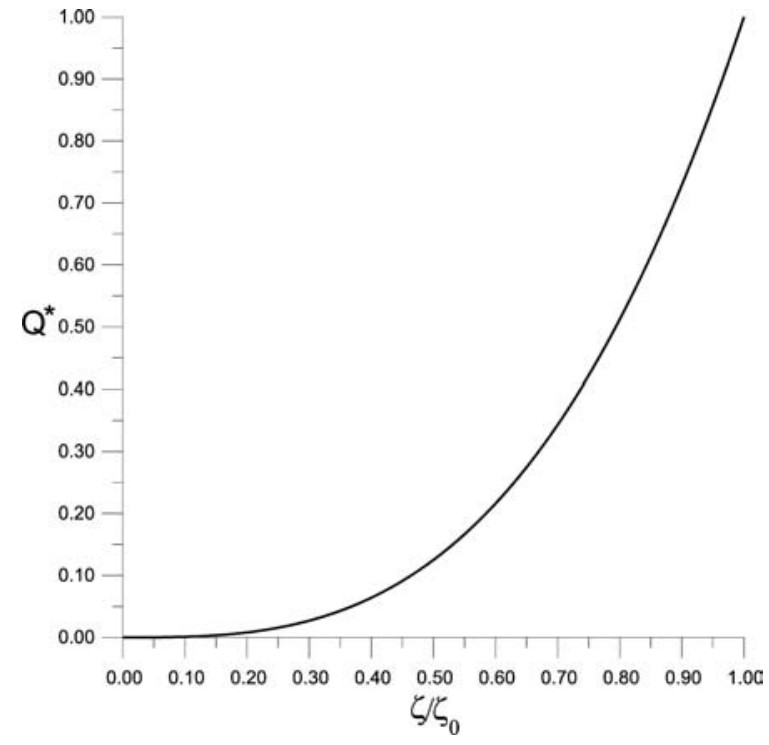

Fig. 6 Plot of dimensionless discharge, $Q^{*}$ versus dimensionless aperture, $\varsigma / \varsigma_{0}$

hold at shallow depths. The dimensionless discharge for $\mathrm{N}-\mathrm{S}$-oriented fractures with dimensionless aperture of 0.30 at these shallow depths is predicted from Fig. 6 to be less than 0.05 , similar to the case for deeper fractures with the same orientation.

The results from the model are consistent with observations derived from the data presented in Fig. 3; the subhorizontal bedding planes are most transmissive near the surface and, with increasing depth, these planes become less dominant hydraulically compared with the steeply-dipping, but less transmissive, fractures that are oriented normal to the minimum horizontal effective principal stress, $S_{h}{ }^{\prime}$. This model also predicts that the high-angle fractures have a narrower depth-independent range of transmissivities than do the subhorizontal bedding planes and that $\mathrm{N}-\mathrm{S}$-oriented fractures have negligible transmissivities.

\section{Conceptual Hydrologic System}

Results derived from the log analyses presented above can be interpreted within the context of the tectonic setting and the stress model to develop a conceptual understanding of the groundwater flow system in much of the Newark Basin. Although details and distinctions unique to each site are apparent from the field data, an idealized aquifer behavior fits within a general framework based upon this collection of information.

Fluid transport occurs through both types of planar features, bedding plane partings and steeply dipping extension fractures, as well as at their intersections (Berkowitz et al. 1994; Park et al. 2001). However, packer test results at the New Jersey site indicate that hydraulic communication across bedding planes is much lower than along bedding planes, implying that most steeply dipping fractures are truncated by bedding and are not 
continuous vertically. This interpretation is consistent with the field observations reported by Houghton (1990) and by Michalski (1990). In addition, gradational sequences of mudstones, siltstones, and sandstones are relatively thin $(<1 \mathrm{~m})$ in the logged wells at the New Jersey site. Thin sandstone units imply a denser population of high-angle fractures that, in turn, should impose more of an anisotropic component to the flow system. Conversely, the sandstone units are substantially thicker at the Pennsylvania site and, consequently, the steeply dipping fractures are sparser with less probability of being intersected by a vertical borehole (Terzaghi 1965).

\section{Texas Case Study Southwest}

\section{Hydrogeologic Setting}

The site for this case study is situated in a valley along the southern edge of the Davis Mountains and near the west Texas city of Alpine (Fig. 7); the area is within the arid and semi-arid Trans-Pecos region. Alluvial deposits in this region reach a maximum thickness of about $40 \mathrm{~m}$ and consist primarily of poorly sorted, sandy to clayey materials that have relatively low hydraulic conductivities. As a result, typical water yields from the shallow alluvium are only sufficient to supply some domestic and livestock wells (McAnulty 1950). The underlying rocks are mostly extrusives of Tertiary age with an aggregate thickness of approximately $1,000 \mathrm{~m}$. These consist of lavas and pyroclastics, specifically tuff, trachyte, rhyolite, and basalt formations (Littleton and Audsley 1957).

Volcanic rocks in the area have low primary porosities and typically make poor aquifers. Nevertheless, some deeper basalts have demonstrated moderate hydraulic transmissivities at scattered locations and, consequently, they are generally thought to form the important water-bearing units in the Alpine area. The transmissivities of the basalts exhibit a highly heterogeneous nature; wells that penetrate some of these rocks produce the largest water yields in the area and supply municipal demands, whereas others contribute very little. Some investigators have suggested that this spatial variability may be due to regional faulting that increases fracture density locally and produces discrete zones of higher permeability (Littleton and Audsley 1957; LBG-Guyton Assoc. 1998).

\section{Geophysical Log Analysis and Results}

Geophysical $\log$ were recorded in six wells located within a valley setting about $7 \mathrm{~km}$ west of Alpine. The Roberts \#1, \#2, and \#3 wells are in the central part of the valley, and the Lewis \#1 well and the Roberts \#4 and \#5 wells are along its flanks (Fig. 7). The downhole measurements and the general testing approach are similar to those described previously for the northeast case study. However, logs obtained in the Roberts \#1, \#4, and \#5 wells were generally of poor quality due to large borehole diameters, steel casing, or intermittent lengths of perforated casing, which precluded the use of several tools. Data presented here are limited to those recorded in the Roberts \#2 and \#3 wells and in the Lewis \#1 well; these wells are labeled in bold lettering in Fig. 7. The gamma and resistivity logs were supplemented with analyses of drill cuttings to construct lilthologic columns for each of these three wells and permeable zones were identified and their transmissivities quantified from the various fluid-property logs (temperature, flow meter, fluid conductivity). The results are illustrated in Fig. 8.

As reported by Morin and Savage (2002), these data reveal two categories of water-producing zones: (1) the upper and lower contacts bounding a dense trachyte unit roughly between 100-150-m depth, and (2) a deeper interval of highly fractured basalts. Numerous discrete fractures within the individual lithologic units overlying the basalts were identified from inspection of the televiewer logs. However, transmissivities associated with these fracture planes were negligible and fluid exchange could only be detected at the trachyte boundaries. Fluid exchange within the interior of a specific unit only occurred in the basalts and this production could not be attributed to individual fractures but rather to highly fractured intervals.

A distinction can be made between the hydrologic properties of these two water-producing categories of fractures based upon well location in this roughly E-Wtrending valley. The two wells situated near the valley center (Roberts \#2 and \#3) exhibit high transmissivities at the trachyte boundaries and lower transmissivity in the deeper basalts for the Roberts \#2 well (Roberts \#3 does not reach the basalts). However, the flank well (Lewis \#1) displays an opposite relation, with the deeper basalts being significantly more permeable than the overlying trachyte contacts. This trend is further supported by the assumption that a driller will drill until significant water yield is achieved and then stop. Shallow wells (Roberts $\# 1$ and \#3) are found near the central valley and deep wells (Lewis \#1, Roberts \#4 and \#5) along the valley flanks (see Fig. 7). The Roberts \#2 well was originally a shallow well, similar to the Roberts \#3 well, but was later deepened into the basalts in hopes of yielding more water.

\section{Tectonic Setting}

The Alpine area forms part of the much larger TransPecos region; its primary structural and tectonic features are described by Dickerson and Muehlberger (1985). The Trans-Pecos is bounded by the Pecos River to the east and the Rio Grande River to the west and south. This region was exposed to three major tectonic events during the Tertiary Period (Price and Henry 1985): (1) Laramide crustal shortening, where the maximum principal compressive stress, $S_{l}$, was east to northeast, (2) magmatism during the middle Eocene to early Oligocene under lower compression, but with stress orientations remaining essentially unchanged, and (3) Basin and Range extension with regional normal faulting. The vertical 
Fig. 7 Locations of field site and wells in west Texas

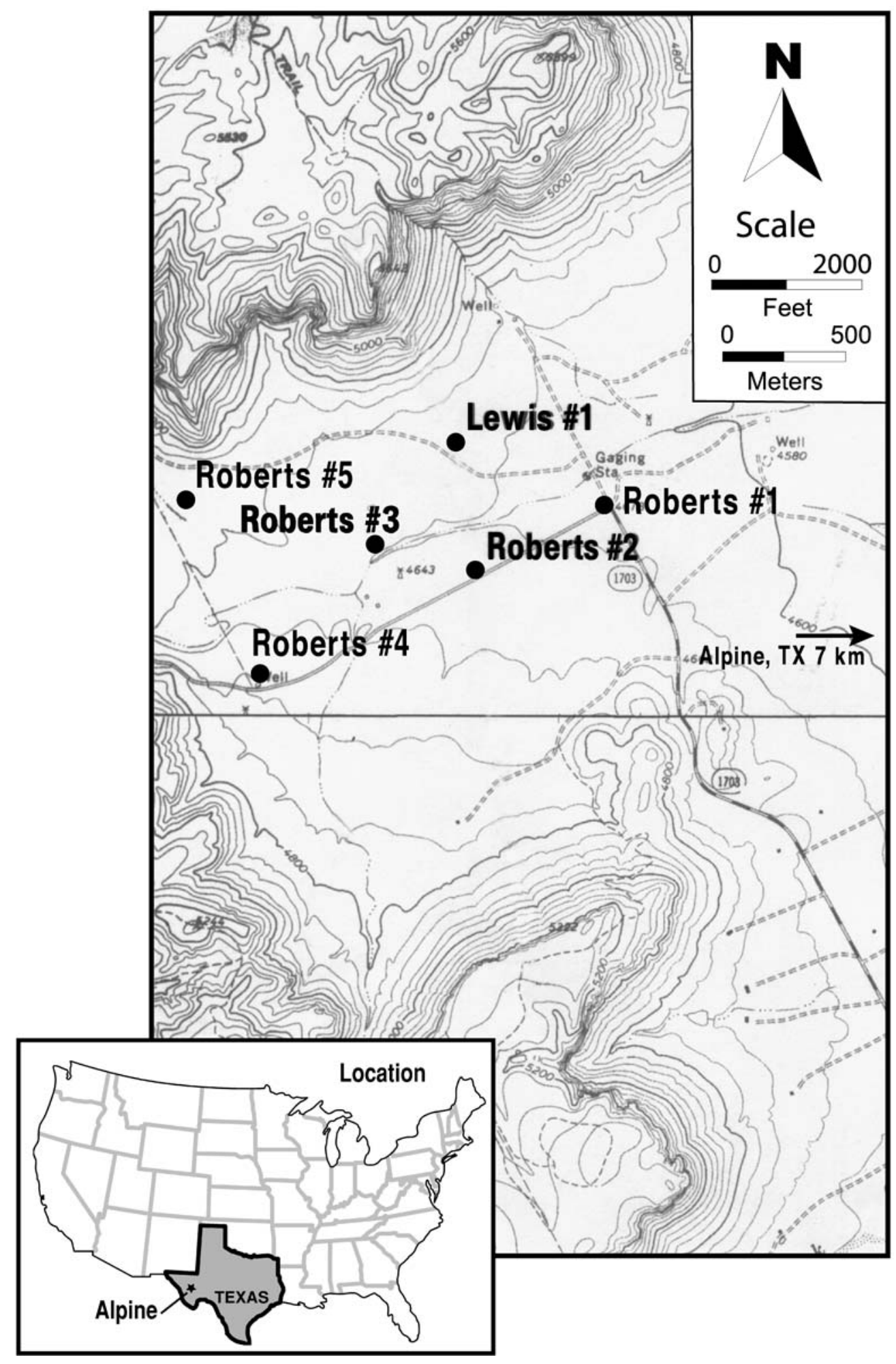

principal stress, $S_{V}$, corresponds to $S_{l}$, the maximum principal stress, in this extensional stress regime and the orientation of the least principal stress, $S_{3}$, has shifted over time.

Earthquake studies indicate that this tectonic environment has continued to evolve (Doser et al. 1992), with
Alpine situated in a transitional zone between competing extensional provinces associated with the southern Rio Grande rift and the southern Great Plains (Zoback and Zoback 1989). Focal mechanism analyses derived from the mainshock and two of the larger aftershocks of the 1995 Alpine earthquake (Doser 1998) describe normal 


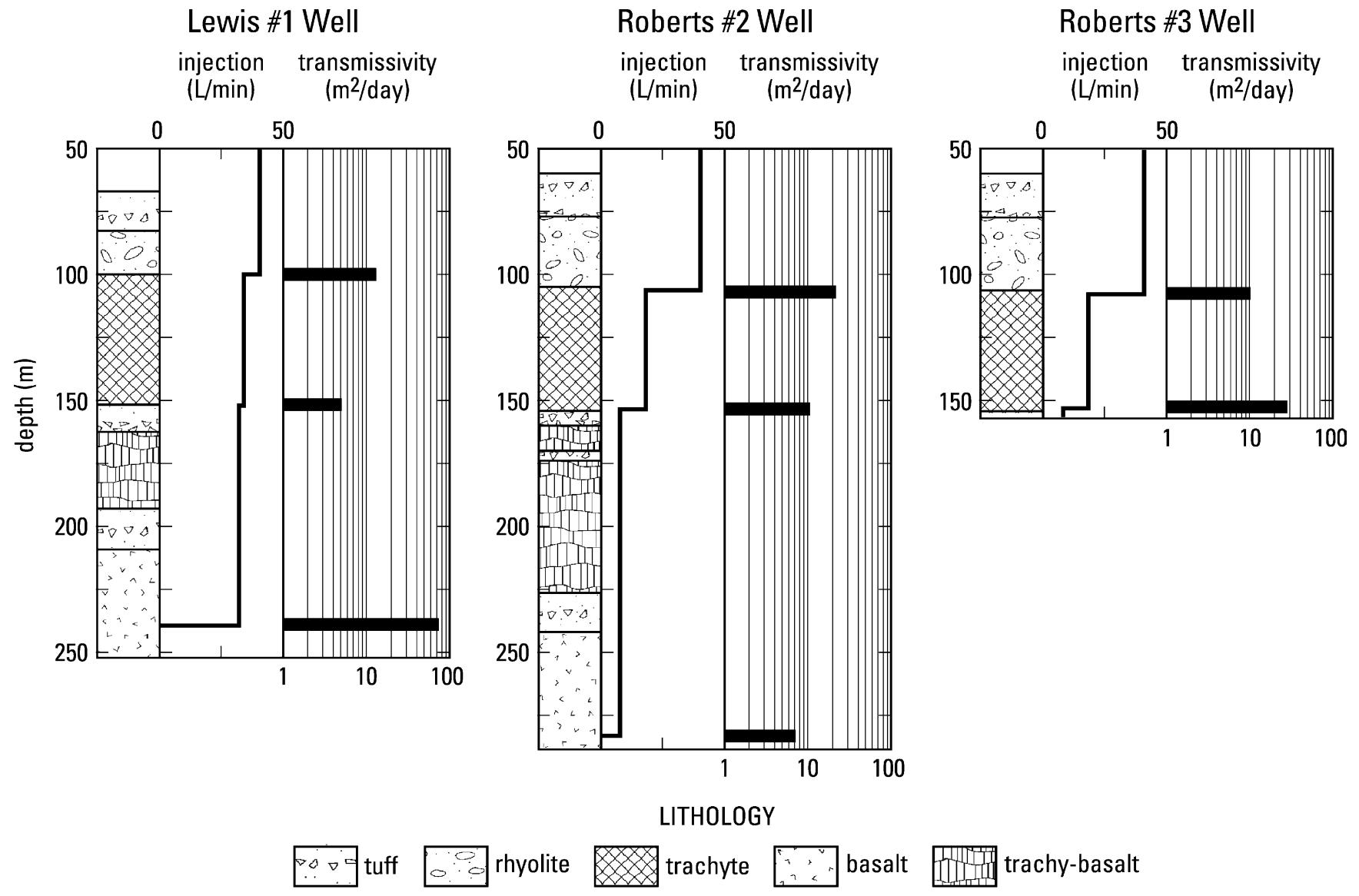

Fig. 8 Lithologic columns constructed from geophysical well logs and drill cuttings, along with vertical distribution of transmissivity determined from injection tests

faulting events with an extensional stress $\left(S_{3}\right)$ direction aligned roughly east-west. This orientation happens to be subparallel to the valley axis at the study site shown in Fig. 7.

\section{Stress model}

Televiewer logs obtained in the Lewis \#1 well on the northern valley flank (Fig. 7) reveal stress-induced breakouts (e.g., Bell and Gough 1979) that have undergone a $90^{\circ}$ shift in orientation with depth, a polarity change that implies an exchange of the maximum, $S_{H}$, and minimum, $S_{h}$, horizontal principal stress directions. Savage and Morin (2002) explain this $90^{\circ}$ shift in $S_{H}$ and $\mathrm{S}_{h}$ with depth by using an analytical model (Savage and Swolfs 1986) for gravity- and tectonically-induced stresses beneath an idealized symmetric and isolated valley. Physical coordinates of the model are aligned with the valley configuration at Alpine and results represent stress conditions in the subsurface at this site.

The vertical distributions of the horizontal in-plane, $\sigma_{x}$, the horizontal out-of-plane, $\sigma_{z}$, the vertical, $\sigma_{y}$, and the shear, $\sigma_{x y}$, stresses for both the valley flank and the central valley predicted by the analytical model are pre- sented in Fig. 9. Further details regarding the development of this model, including values used for various rock properties and assumptions made in simplifying the valley geometry, can be found in Savage and Morin (2002). The curves in Fig. 9 predict the polarity reversal of $S_{H}$ and $S_{h}$ with depth (i.e., the profiles of $\sigma_{x}$ and $\sigma_{z}$ intersect) and identify two prominent differences in stress conditions with respect to location within the valley setting. Tensile (negative) stresses are larger in the shallow part of the central valley, but shear stresses are zero from model symmetry constraints. Conversely, the valley flank displays lower tensile stresses near the surface, but has non-zero shear stresses that become more negative with depth. These differences are a direct consequence of topography and are magnified by the alignment of the maximum far-field tectonic stress normal to the valley axis.

The hydrologic significance of these location-dependent stress distributions within a valley setting can be examined by means of the stress invariants $I_{l}$ and $J_{2}$ and their relation to the Drucker-Prager failure criterion (Jaeger and Cook 1977; Chen and Saleeb 1982). The first stress invariant, $I_{l}$, is independent of the choice of axes and is defined as

$I_{1}=\sigma_{x}+\sigma_{y}+\sigma_{z}$

The mean normal stress may be subtracted from the individual stress components to arrive at another set of components that represents stress deviation. Following the 
A

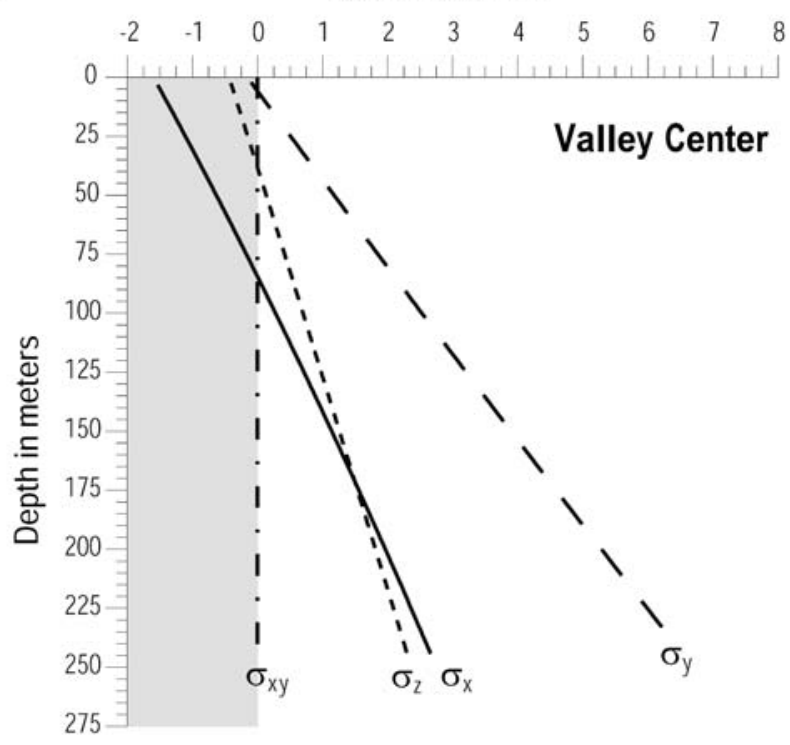

B

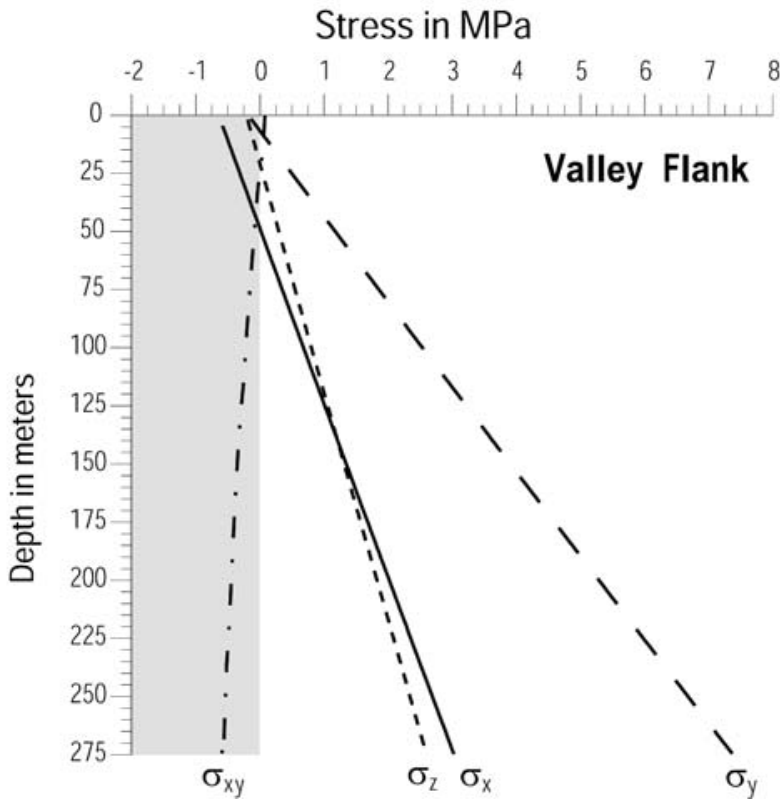

Fig. 9 Vertical distribution of normal and shear stresses computed from the analytic topographic stress model $\mathbf{A}$ for the central valley and $\mathbf{B}$ along the valley flank (modified from Savage and Morin 2002)

assumption of plane-strain conditions imposed by the analytical model (Savage et al. 1985), $\sigma_{y z}=\sigma_{z x}=0$, the equivalent deviatoric stress invariant, $J_{2}$, is defined as,

$J_{2}=1 / 6\left[\left(\sigma_{y}-\sigma_{z}\right)^{2}+\left(\sigma_{z}-\sigma_{x}\right)^{2}+\left(\sigma_{x}-\sigma_{y}\right)^{2}\right]+\sigma_{x y}^{2}$

The normal stress invariant, $I_{l}$, essentially represents compression under triaxial loading and a general closing of fractures (Niemi et al. 2000). Conversely, the deviatoric stress invariant, $J_{2}$, represents distortion and the potential for propagation and/or opening of fractures. Lab- oratory studies have demonstrated that fractures form, open, and may coalesce when submitted to deviatoric stresses. As this process of forming networks of fractures develops, hydraulic communication within the rock mass should improve and, consequently, the transmissivity should be enhanced. Thus, the two stress invariants describe fundamentally different deformational processes and their magnitudes, when expressed in terms of a failure criterion (Drucker and Prager 1952), may provide some quantitative measure of fracture connectivity within a rock mass.

The Drucker-Prager criterion is a three-dimensional generalization of the two-dimensional Coulomb criterion (Jaeger and Cook 1977) and is expressed as a relationship between $\mathrm{I}_{1}$ and $J_{2}$ by means of a stability factor.

$F_{D P}=\frac{\alpha I_{1}+k}{\sqrt{J_{2}}}$

The material constants $\alpha$ and $k$ can be expressed in terms of the coefficient of sliding friction, $\mu$, and the cohesion, $C$, for plane strain conditions as,

$\alpha=\frac{\mu}{\sqrt{9+12 \mu^{2}}}$

$k=\frac{3 C}{\sqrt{9+12 \mu^{2}}}$

The value of $F_{D P}$ computed from Eq (6) provides a quantitative means of assessing the deformation of a rock mass and its impact on the distribution and extent of fracture networks. Where $F_{D P} \leq 1$, driving deviatoric stresses represented by $\sqrt{J_{2}}$ overcome resisting stresses given by $\left(\alpha I_{l}+k\right)$, with possible opening and/or coalescing of fractures. Where $F_{D P}>1$, resisting stresses are dominant and consequent opening of fractures is contained.

The vertical distributions of the Drucker-Prager stability factor with respect to location in a valley setting and based upon the stress profiles of Fig. 9 are depicted as shaded areas in Fig. 10. Bounds on these areas are defined from the range of rock cohesion values, $C$, used in the calculations $(0.5 \mathrm{MPa} \leq C \leq 1.0 \mathrm{MPa}$; Morin and Savage 2002). These magnitudes of $F_{D P}$ are of particular interest because transmissivity distributions differ significantly between well locations at this Alpine site, particularly in the lowermost fractured basalts. The profiles in Fig. 10 imply that fracture connectivity systematically increases with increasing depth in the flank wells, whereas the central valley wells appear to have only a moderate degree of fracture connectivity throughout. The transmissivity distributions measured in three wells (Fig. 8) are consistent with these trends.

\section{Conceptual Hydrologic System}

The stress model, conceived from logging results and developed from a complementary analytical model for the influence of a valley on crustal tectonic and gravitational stresses, provides a generalized understanding of aquifer 


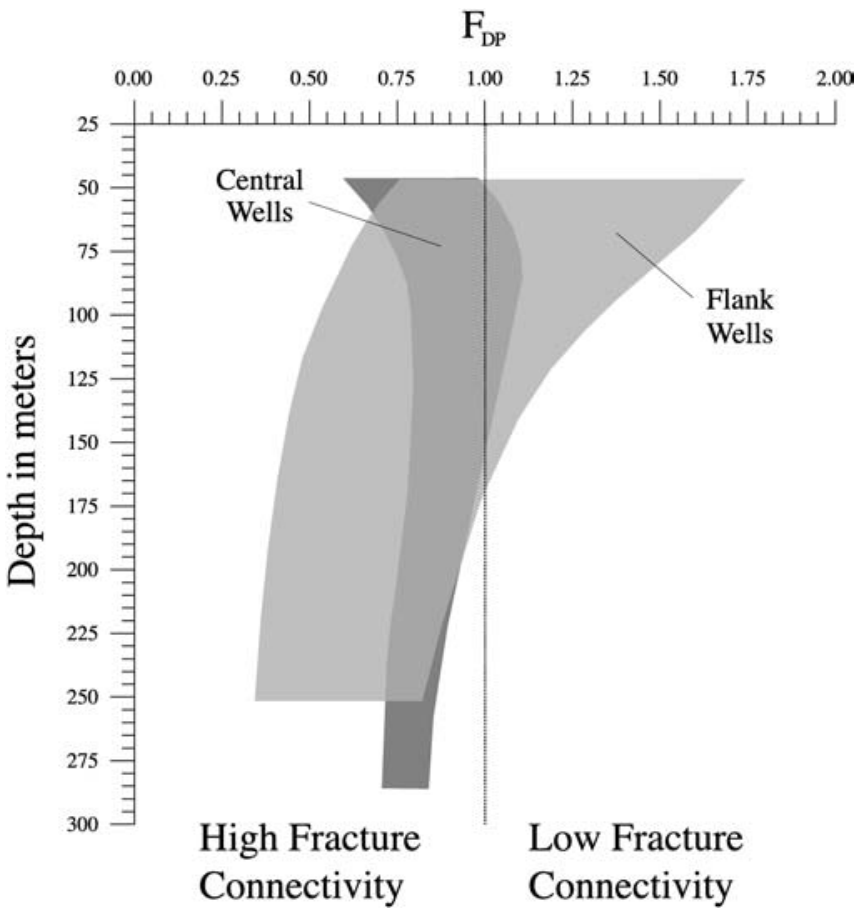

Fig. 10 Distributions (shaded areas) of the Drucker-Prager stability factor, $F_{D P}$, as a function of depth for two locations in a valley setting (modified from Morin and Savage 2002). Bounds on the shaded areas are determined from range of rock cohesion values, $C$, used in the calculations $(0.5 \mathrm{MPa} \leq C \leq 1.0 \mathrm{MPa})$

characteristics near Alpine, Texas. The correlation identified between depth of the prominent aquifer and location within the valley appears to be a direct consequence of topographically modified tectonic and gravitational stresses, with the effect enhanced by the fortuitous alignment of the tectonic stress field with the trend of the valley.

Two types of productive zones are common to the three wells investigated, though their relative influence on the hydrologic system varies based upon location within the valley configuration. The upper and lower boundaries of a dense, 50-m-thick trachyte unit provide discernible pathways for fluid flow in all wells and these two shallow horizons define the major aquifer in the central valley. Along the valley flanks, these contacts remain somewhat permeable, but the major aquifer is now associated with a deeper unit of highly fractured basalts. Although numerous discrete fractures are identified in all lithologic units penetrated by these wells, their transmissivities are negligible and they do not contribute to the general hydrologic system, even when they are favorably aligned with the contemporary stress field. It appears that these fracture networks are generally below the critical limit for percolation (Long et al. 1996). Only the fractured interiors of the deep basalt units can be characterized as being productive as a formation.

\section{Discussion}

Two cases have been presented where rock-mechanics principles are applied to characterize fractured-rock aquifers subjected to crustal stresses. At the northeast site (Newark Basin), a sedimentary basin contains deposits that have been deformed under an ancient stress field in either a ductile or a brittle manner, depending upon lithology. The hydrologic response of the aquifer is related to the types of features that serve as pathways for fluid flow and to their relationship with the current regional stress field. Thus, flow characteristics in the Newark Basin are related to fracture type, fracture type is a function of lithology, and aquifer transmissivity has an important anisotropic component due to the systematic alignment of many of these pathways to the stress field.

At the southwest site (west Texas), the superposition of tectonic and topographic stresses acting upon a series of extrusive rocks produces a trend in fracture connectivity with depth that varies spatially in the valley setting. The depth of the dominant aquifer corresponds to the location of densely connected fractures within the rock mass rather than to discrete and preferentially aligned planes. In this case, the rock mass at a certain depth and location has been subjected to a combination of stresses that has propped open fractures beyond a percolation threshold to form an interconnected and permeable network.

These two cases demonstrate how the response of fractured rock to imposed stresses can impact the predominant hydrologic characteristics of aquifers. Although the study sites involve different rock types and different stress environments, the link between stress, fractures, and fluid flow is common and can be traced through the analysis of geophysical log data and the complementary development of stress models.

Acknowledgments The authors are grateful to C. Neuzil and O. Stephansson for their thorough and insightful reviews that improved this manuscript considerably.

\section{References}

Bai T, Pollard DD (2000) Fracture spacing in layered rocks: a new explanation based on the stress transition. J Struct Geol 22:43-47

Bandis SC, Lumsden AC, Barton NR (1983) Fundamentals of rock joint deformation. Int J Rock Mech Sci Geomech Abstr 20:249-268

Barton CA, Zoback MD, Moos D (1995) Fluid flow along potentially active faults in crystalline rock. Geology 23(8):683-686

Beeler NM, Hickman SH (2001) A note on contact stress and closure in models of rock joints and faults. Geophys Res Lett 28:607-610

Bell JS, Babcock EA (1986) The stress regime of the Western Canadian Basin and implications for hydrocarbon production. Bull Can Petrol Geol 34:364-378

Bell JS, Gough DI (1979) Northeast-southwest compressive stress in Alberta: evidence from oil wells. Earth Planet Sci Lett 45:475-482

Berkowitz B, Naumann C, Smith L (1994) Mass transfer at fracture intersections: an evaluation of mixing models. Water Resour Res 30:1765-1773 
Brown SR, Scholz CH (1986) Closure of rock joints. J Geophys Res 89:4939-4948

Bruno MS, Bovberg CA, Nakagawa FM (1991) Anisotropic stress influence on the permeability of weakly-cemented sandstones. In: Roegiers E (ed) Rock mechanics as a multi-disciplinary science. Balkema, Rotterdam, pp 375-383

Chen WF, Saleeb AF (1982) Constitutive equations for engineering materials, vol 1. Wiley, New York

Clemo T, Smith L (1997) A hierarchical model for solute transport in fractured media. Water Resour Res 33:1763-1783

Cook NGW (1992) Natural joints in rock: mechanical, hydraulic and seismic behaviour and properties under normal stress. Int J Rock Mech Sci Geomech Abstr 29:198-223

Dickerson PW, Muehlberger WR (eds) (1985) Structure and tectonics of Trans-Pecos Texas. West Texas Geology Society Field Conference, Publ 85-81

Doser DI (1998) Seismic hazards of the Rio Grande rift/Great Plains transition zone in west Texas and southern New Mexico. Seismol Res Lett 69:141

Doser DI, Baker MR, Luo M, Marroquin P, Ballesteros L, Kingwell J, Diaz HL, Kaip G (1992) The not so simple relationship between seismicity and oil production in the Permian Basin, west Texas. Pure Appl Geophys 139:481-506

Drucker DC, Prager W (1952) Soil mechanics and plastic analysis or limit design. Quart Appl Math 10:157-165

Einstein HH, Dershowitz WS (1990) Tensile and shear fracturing in predominantly compressive stress fields a review. Eng Geol 29:149-172

Ferrill DA, Winterle J, Wittmeyer G, Sims D, Colton S, Armstrong A (1999) Stressed rock strains groundwater at Yucca Mountain, Nevada. GSA Today 9(5):1-8

Froelich AJ, Robinson GR Jr (eds) (1988) Studies of the Early Mesozoic basins of the eastern United States. US Govt Printing Office. US Geological Survey Bull 1776

Gentier S, Hopkins D, Riss J (2000) Role of fracture geometry in the evolution of flow paths under stress. In: Dynamics of fluids in fractured rock. AGU Geophysical Monograph 122, Washington, DC, pp 169-184

Hearst JR, Nelson PH, Paillet FL (2000) Well logging for physical properties, 2nd edn. Wiley, New York

Heffer KJ, Fox RJ, McGill CA, Koutsabeloulis NC (1995) Novel techniques show links between reservoir flow directionality, Earth stress, fault structure and geomechanical changes in mature water floods. Proceedings of the SPE Annual Technical Conference and Exhibition, Dallas, Texas, pp 7787

Hillis RR (1998) The influence of fracture stiffness and the in situ stress field on the closure of natural fractures. Petrol Geosci 4:57-65

Houghton HF (1990) Hydrogeology of the early Mesozoic rocks of the Newark Basin, NJ. In: Kroll RL, Brown JO (eds) Proc Aspects of Groundwater in New Jersey. Geological Association of New Jersey 7th Annual Meeting, New Jersey, E1-E36

Hudson JA, Harrison JP (1997) Engineering rock mechanics: an introduction to the principles. Elsevier, New York

Jaeger JC, Cook NGW (1977) Fundamentals of rock mechanics, 2nd edn. Wiley, New York

LBG-Guyton Assoc (1998) Preliminary evaluation of potential groundwater supply development for the city of Alpine, Texas. LBG-Guyton Assoc. Texas

Littleton RT, Audsley GL (1957) groundwater geology of the Alpine area, Brewster, Jeff Davis and Presidia Counties. Texas Board Water Eng Bull 5712

Long JCS, Aydin A, Brown SR, Einstein HH, Hestir K, Hsieh PA, Myer LR, Nolte KG, Norton DL, Olsson OL, Paillet FL, Smith JL, Thomsen L (1996) Rock fractures and fluid flow: contemporary understanding and applications. National Academy Press, Washington, DC

Lyttle PT, Epstein JB (1987) Geologic map of the Newark 1x2 quadrangle. New Jersey, Pennsylvania, and New York, 1:250,000 USGS Misc. Investigations Series Map I-1715
McAnulty WN (1950) Geology and groundwater resources of Alpine and adjacent territory, Brewster County, Texas. Report for the City of Alpine

Michael AJ (1984) Determination of stress from slip data. J Geophys Res 89:11517-11526

Michalski A (1990) Hydrogeology of the Brunswick (Passaic) Formation and implications for groundwater monitoring practice. Ground Water Monitor Rev 10:134-143

Michalski A, Britton R (1997) The role of bedding fractures in the hydrogeology of sedimentary bedrock evidence from the Newark Basin, New Jersey. Ground Water 35:318-327

Moreno L, Neretnieks I (1993) Fluid flow and solute transport in a network of channels. J Contam Hydrol 14:163-192

Morin RH, Savage WZ (2002) Topographic stress perturbations in Southern Davis Mountains, west Texas: II. Hydrogeologic implications. J Geophys Res 107:B12, 2340, doi: 10.1029/ 2001JB000488

Morin RH, Carleton GB, Poirier S (1997) Fractured-aquifer hydrogeology from geophysical logs; the Passaic Formation, New Jersey. Ground Water 35:328-338

Morin RH, Senior LA, Decker ER (2000) Fractured-aquifer hydrogeology from geophysical logs: Brunswick Group and Lockatong Formation, Pennsylvania. Ground Water 38: 182-192

Niemi A, Konitio K, Kuusela-Lahtinen A (2000) Hydraulic characterization and upscaling of fracture networks based on multiple-scale well test data. Water Resour Res 36:3481-3497

Olsen PE (1980) The latest Triassic and early Jurassic formations of the Newark Basin (eastern North America, Newark Supergroup): stratigraphy, structure, and correlation. New Jersey Acad Sci Bull 25:25-51

Ouillon G, Castaing C, Sornette D (1996) Hierarchical geometry of faulting. J Geophys Res 101:5477-5487

Park Y-J, Lee K-K, Berkowitz B (2001) Effects of junction transfer characteristics on transport in fracture networks. Water Resour Res 37:909-923

Parker RA, Houghton HF, McDowell RC (1988) Stratigraphic framework and distribution of early Mesozoic rocks of the Northern Newark Basin, New Jersey and New York. In: Froelich AJ, Robinson GR Jr (eds) Studies of the Early Mesozoic basins of the Eastern United States. USGS. Bull 1776:31-39

Pollard DD, Aydin A (1988) Progress in understanding jointing over the past century. Geol Soc Am Bull 100:1181-1204

Price JG, Henry CD (1985) Summary of Tertiary stress orientations and tectonic history of Trans-Pecos Texas. In: Dickerson PW, Muehlberger WR (eds) Structure and tectonics of TransPecos Texas. West Texas Geological Society Field Conference Publ 85-81, pp 149-151

Priest SD, Hudson JA (1976) Discontinuity spacings in rock. Int J Rock Mech Mineral Sci Geomech Abstr 13:135-148

Renshaw CE (2000) Fracture spatial density and the anisotropic connectivity of fracture networks. In: Dynamics of fluids in fractured rock. AGU Geophysical Monograph 122, Washington, DC, pp 203-211

Savage WZ, Morin RH (2002) Topographic stress perturbations in Southern Davis Mountains, west Texas: I. Polarity reversal of principal stresses. J Geophys Res 107:B12, 2389, doi: 10.1029/2001JB000484

Savage WZ, Swolfs HS (1986) Tectonic and gravitational stress in long symmetric ridges and valleys. J Geophys Res 91: $3677-3685$

Savage WZ, Swolfs HS (1987) SLIP-A FORTRAN computer program for computing the potential for sliding on arbitrarily oriented weakness planes in triaxial stress states. USGS Openfile Report 87-82

Savage WZ, Swolfs HS, Powers PS (1985) Gravitational stresses in long symmetric ridges and valleys. Int J Rock Mech Mining Sci Geomech Abstr 22:291-302

Sayers CM (1990) Stress-induced fluid flow anisotropy in fractured rock. Trans Porous Media 5:287-297

Schlische RW (1992) Structural and stratigraphic development of the Newark extensional basin, eastern North America: evi- 
dence for the growth of the basin and its bounding structures. Geol Soc Am Bull 104:1246-1263

Seeber L, Armbruster JG, Kim WY, Barstow N, Scharnberger C (1998) The 1994 Cacoosing Valley earthquakes near Reading Pennsylvania: a shallow rupture triggered by quarry unloading. J Geophys Res 103:24505-24521

Simpson G, Guéguen Y, Schneider F (2001) Permeability enhancement due to micro-crack dilatancy in the damage regime. J Geophys Res 106:3999-4016

Stone JR, Barlow PM, Starn JJ (1996) Geohydrology and conceptual model of a groundwater flow system near a Superfund site in Cheshire, Connecticut. US Geological Survey Open-File Rep 96-162
Terzaghi R (1965) Sources of error in joint surveys. Geotechnique 15:287-304

Vecchioli J, Carswell LD, Kasabach HF (1969) Occurrence and movement of ground water in the Brunswick Shale at a site near Trenton, New Jersey. US Geological Survey Professional Paper 650-B, B154-B157

Witherspoon PA, Wang JSY, Iwai K, Gale JE (1980) Validity of the cubic law for fluid flow in a deformable rock fracture. Water Resour Res 16:1016-1024

Zoback ML, Zoback MD (1989) Tectonic stress field of the conterminous United States. In: Parker LC, Mooney WD (eds) Geophysical framework of North America. Mem Geol Soc Am 172:523-539 